\title{
Evaluation of the attitude of students from medical faculties of the Medical University of Warsaw (Poland) and University of Basel (Switzerland) towards the development of communication competence
}

\author{
Lucyna Iwanow' ${ }^{1}$, Mariusz Jaworski', Joanna Gotlib', Mariusz Panczyk ${ }^{1}$ \\ ${ }^{1}$ Department of Education and Research in Health Sciences, Medical University of Warsaw, Poland \\ Iwanow L, Jaworski M, Gotlib J, Panczyk M. Evaluation of the attitude of students from medical faculties of the Medical University of \\ Warsaw and University of Basel towards the development of communication competence. Med Og Nauk Zdr. 2019; 25(2): 95-99. doi: 10.26444/ \\ monz/109661
}

\begin{abstract}
Introduction. Communication skills of medical staff have a significant impact on the effectiveness of the therapeutic process and patient safety. Positive attitudes towards learning these competences may in the future result in a desire to develop them further.

Objective. The aim of the study was to assess the attitude of medical students towards the development of communication skills depending on the dominant health care system - private (Switzerland) and State (Poland).

Materials and method. The pilot study covered a population of 261 students from the Medical University of Warsaw (MUW), Poland, and University of Basel (UB), Switzerland. A voluntary and anonymous survey was carried out using a standardised CSAS questionnaire, consisting of 26 items presented in two subscales - positive (PAS) and negative (NAS), evaluated according to a 5-point Likert scale. The difference between the attitude of students from Poland and Switzerland was evaluated using the Student's t-test together with the calculation of Cohen's d effect size.

Results. Polish and Swiss students presented a neutral attitude towards learning communication skills and towards their own skills in this area. At the same time, the attitudes of UB students were slightly more positive than those of MUW students (UB: $90.4 / 130$ versus MUW: $88.9 / 130, t=2.555 ; p=0.011$ ). In the area of self-assessment of communication skills, the obtained results were at a low level (average in the range from 2.2 to 2.7/5). There were no statistically significant differences in this field between students from the two countries.

Conclusions. A neutral attitude may have a negative impact on effective and successful cooperation with the patient and members of an interdisciplinary team in the future. It is therefore reasonable to introduce teaching of communication skills into the curriculum of medical studies.
\end{abstract}

\section{Key words}

soft skills, Communication Skills Attitude Scale, students, communication with a therapeutic team

\section{INTRODUCTION}

Effective communication between the patient and members of the interdisciplinary team, as well as between the nurse and physician, is necessary to ensure high quality care, effective therapeutic process and patient safety [1].

Based on scientific reports, it can be concluded that there is a need to complete the curricula of medical studies by teaching soft skills and promoting a positive attitude towards learning them [2-4]. Developing a positive attitude to learning soft skills by medical students can inspire a future desire to develop the skills and improve them in post-graduate studies.

Modern medical education should not only strengthen communication skills, but should also be adapted to the current health care system; for example, the system of medical care in Switzerland, which is based on private benefits. In addition, according to the reports of Euro Health Consumer Index (EHCI), Switzerland occupies a very high position in terms of quality of medical services [5]. The opposite of

Address for correspondence: Lucyna Barbara Iwanow, Warsaw Medical University, Poland

E-mail: lucyna.iwanow@wum.edu.pl

Received: 2 April 2019; Accepted: 27 May 2019 the Swiss system is the system of State health care, which dominates, for example, in Poland.

Poland is a country that teaches according to the rules established during the Bologna Process. Collins and Hewer [6] in their work describing the influence of the Bologna process on teaching the nurse profession showed Switzerland as a divided country. The French part of Switzerland teaches in accordance with the Bologna rules, while the German part still believes that teaching the nursing profession should be strictly practical $[6,7]$.

The nurse education system at medical universities in Poland and Switzerland is relatively similar. In both countries there are two levels - bachelor and master's studies. Differences between the two systems occur in the second-degree studies. In Switzerland, they are more similar to the post-graduate education of nurses in the field of specialization in Poland. In Switzerland, nurses who are in master's studies choose a specialization of study from among paediatric nursing, oncology nursing, public health or administration. Master's studies in Poland, in turn are pre-vocational - they prepare nurses for conducting scientific research, management of nursing staff, and also prepare them for the teaching of future nurses [6-9]. 


\section{OBJECTIVE}

The aim of the study was to assess the attitudes of medical students towards shaping communication skills, depending on the prevailing health care system - private (Switzerland) or State (Poland).

\section{MATERIALS AND METHOD}

The pilot study covered a population of 261 students of the Medical University of Warsaw (MUW, N =142) and University of Basel (UB, $N=119)$. The respondents represented 9 medical speciality areas: dietetics, electrocardiology, pharmacy, physical therapy, medicine for physicians, nursing, obstetrics, medical rescue and public health. The mean age was 22.6 years (median: 22, min. 19, $\max 55$, SD: 2.95). Women constituted a large majority of the study population (78.5\%).

The study was conducted in March and April 2017. Participation was voluntary and anonymous. The tool was made available to all participants of the study via a social website in the form of a Google electronic questionnaire in 2 language versions - Polish and English. Students from the University of Basel completed the original English version of the questionnaire, while students of the Medical University of Warsaw completed the Polish version validated and described by Panczyk et al. [10].

The Bioethics Committee of the Medical University of Warsaw evaluated the proposal and concluded that there was no need to obtain ethical approval to conduct the survey [11].

The study was based on a standardised Communication Skills Attitude Scale (CSAS) questionnaire [12]. This is one of the most popular standardised tools used to measure the attitude towards learning communication skills. Initially, CSAS was intended to investigate the attitudes of students of medicine towards learning communication skills. With regard to good psychometric parameters and many language versions, the scale enables a comparison of results between different countries and different faculties of medical studies [13-28].

The questionnaire consists of 26 statements concerning the significance of communication skills in professional practice, evaluated according to a 5-point Likert scale

(1 - strongly disagree, 2 - disagree, 3 - neutral, 4 - agree, 5 - strongly agree). The scale is divided into 2 subscales: positive affect scale (PAS) and negative affect scale (NAS), containing 13 statements. An attitude is evaluated based on the total score for the scale, whereby the answers on the NAS scale are recoded before being added (reverse score). The total maximum number of points that can be obtained by completing the questionnaire is 130 .

The authors added 4 questions concerning the selfassessment of one's communication skills to the CSAS. The questions were evaluated according to a 5-point Likert scale ( 1 - very poor, 4 - poor, 3 - no opinion, 4 - good, 5 - very good). The survey participants were asked to evaluate their skills related to cooperation with a patient, the patient's family, students in practical classes, and other members of a therapeutic team.

The scores obtained for different scale items were developed by means of descriptive statistics (mean and standard deviation), and the total number of points was calculated based on a key. The differences in the attitude of MUW and
UB students were evaluated using Student's t-test together with the calculation of Cohen's $d$ effect size. The value of 0.05 was assumed to be the default level of statistical significance for all analyses. The calculations were performed using STATISTICA version 13.3 (Dell, Inc.), according to the licence of the MUW.

\section{RESULTS}

Regardless of the University, students presented a neutral attitude towards learning communication skills (M: 89.4/130), with MUW students presenting a slightly less approving attitude than UB students (MUW: 88.9/130 versus UB: $90.4 / 130, t=-2.555 ; \mathrm{p}=0.011)$. Details of the evaluation of the students> attitude towards learning communication skills (Tab. 1).

The students ranked their skills related to communication with fellow students during clinical practice (MUW: 2.7/5 versus UB: $2.8 / 5 ; \mathrm{t}=-1.334 ; \mathrm{p}=0.183$ ) as the highest. Communication skills with members of the interdisciplinary team $(2.6 / 5$ for MUW and $U B ; t=0.279 ; \mathrm{p}=0.780)$ and the patient $(2.6 / 5$ for MUW and $U B ; t=0.082 ; \mathrm{p}=0.935)$ were ranked lower. The students evaluated their skills related to communication with the patient/s family to be the lowest (MUW: $2.3 / 5$ versus UB: $2.2 / 5 ; \mathrm{t}=0.844 ; \mathrm{p}=0.399$ ).

\section{DISCUSSION}

The assessed attitude of the studied groups of students, regardless of the university, was neutral. The obtained result confirms the validity of the implementation of elements of work in groups made up by students of various majors in an early stage of study. Such action is aimed at creating a positive attitude and developing communication skills when assembling therapeutic teams.

Shaping a positive attitude towards the acquisition of communication skills can be achieved by using the Social Learning Theory (SLT) in practice. The SLT was developed by Bandura [29]. According to this concept, using observations and direct experience, students can demonstrate the importance of communication skills in clinical practice. However, in order for modelling learning to have a positive effect, tutoring-based teaching should be introduced. Tutoring is a didactic method based on not only developing communication skills in direct contact, but also strengthening the creativity for students' independence [30]. Thanks to this method, the educational process will be able to strengthen positive attitudes towards acquiring and improving communication skills among medical students.

The scientific literature contains a number of studies regarding the attitudes of medical students and health scientists towards learning communication skills, which is often performed by means of a CSAS questionnaire [14, $18-20,27,28,31$ ]. Rees et al. [32], the authors of the original version of the tool, studied a group of 225 first-year students of medicine. Besides the proper questionnaire describing 26 attitudes, a questionnaire concerning self-assessment of communication skills was added. The median result of the study population was $3.0 / 5$, which meant that students did not have well-defined opinions on communication skills. In the authors' own study, the median response of students 
Table 1. Attitude of students towards acquiring communication skills

\begin{tabular}{|c|c|c|c|c|c|c|c|}
\hline \multirow{2}{*}{ Items / Subscales } & \multicolumn{2}{|c|}{ MUW } & \multicolumn{2}{|c|}{ UB } & \multirow[t]{2}{*}{$t^{*}$} & \multirow[t]{2}{*}{$\mathrm{p}$} & \multirow[t]{2}{*}{$d^{* *}$} \\
\hline & M & SD & M & SD & & & \\
\hline \multicolumn{8}{|l|}{ PAS } \\
\hline 1. In order to be a good practitioner I must have good communication skills & 3.0 & 0.15 & 3.0 & 0.16 & 0.758 & 0.449 & - \\
\hline 4. Developing my communication skills is just as important as developing my knowledge of medicine & 2.7 & 0.58 & 2.5 & 0.73 & 3.686 & 0.000 & 0.32 \\
\hline 5. Learning communication skills has helped or will help me respect patients & 2.8 & 0.52 & 2.7 & 0.61 & 1.803 & 0.072 & - \\
\hline 9. Learning communication skills has helped or will help facilitate my team-working skills & 3.0 & 0.25 & 2.7 & 0.56 & 5.682 & 0.000 & 0.79 \\
\hline 10. Learning communication skills has improved my ability to communicate with patients & 3.0 & 0.18 & 2.7 & 0.45 & 6.937 & 0.000 & 1.01 \\
\hline 12. Learning communication skills is fun & 2.1 & 0.74 & 2.1 & 0.75 & 0.147 & 0.883 & - \\
\hline 14. Learning communication skills has helped or will help me respect my colleagues & 2.7 & 0.64 & 2.3 & 0.76 & 4.756 & 0.000 & 0.59 \\
\hline $\begin{array}{l}\text { 16. Learning communication skills has helped or will help me recognise patients> rights regarding } \\
\text { confidentiality and informed consent }\end{array}$ & 2.4 & 0.75 & 2.6 & 0.62 & -2.497 & 0.013 & 0.28 \\
\hline 17. Communication skills teaching would have a better image if it sounded more like a science subject & 2.2 & 0.81 & 1.6 & 0.80 & 5.775 & 0.000 & 0.74 \\
\hline 21. I think itıs really useful learning communication skillsfor the medical degree & 2.9 & 0.36 & 2.9 & 0.33 & -0.425 & 0.671 & - \\
\hline 23. Learning communication skills is applicable to learning medicine & 2.2 & 0.72 & 2.2 & 0.72 & -0.118 & 0.906 & - \\
\hline 25. Learning communication skills is important because my ability to communicate is a lifelong skill & 2.8 & 0.47 & 2.9 & 0.36 & -1.299 & 0.195 & - \\
\hline Total PAS & 33.2 & 3.13 & 33.1 & 3.70 & 0.205 & 0.838 & - \\
\hline \multicolumn{8}{|l|}{ NAS } \\
\hline 2. I canst see the point in learning communication skills & 1.1 & 0.34 & 1.1 & 0.42 & -1.153 & 0.250 & - \\
\hline 3. Nobody is going to fail their medical degree for having poor communication skills & 1.7 & 0.72 & 2.1 & 0.89 & -4.064 & 0.000 & 0.51 \\
\hline 6. I haven t got time to learn communication skills & 1.6 & 0.84 & 1.4 & 0.61 & 3.228 & 0.001 & 0.26 \\
\hline 8. I canst be bothered to turn up to sessions on communication skills & 1.4 & 0.62 & 1.6 & 0.68 & -2.781 & 0.006 & 0.31 \\
\hline 11. Communication skills teaching states the obvious and then complicates it & 2.3 & 0.75 & 1.8 & 0.78 & 6.214 & 0.000 & 0.66 \\
\hline 13. Learning communication skills is too easy & 1.9 & 0.77 & 1.4 & 0.63 & 5.780 & 0.000 & 0.69 \\
\hline 19. I donst need good communication skills to be a practitioner & 1.2 & 0.52 & 1.1 & 0.42 & 1.943 & 0.053 & - \\
\hline 20. I find it hard to admit to having some problems with my communication skills & 1.8 & 0.87 & 1.7 & 0.76 & 0.976 & 0.330 & - \\
\hline 22. My ability to pass exams will get me through medical school rather than my ability to communicate & 2.2 & 0.82 & 2.6 & 0.75 & -3.988 & 0.000 & 050 \\
\hline 24. I find it difficult to take communication skills learning seriously & 1.6 & 0.80 & 1.5 & 0.75 & 1.913 & 0.057 & - \\
\hline 26. Communication skills learning should be left to psychology students, not medical students & 1.2 & 0.49 & 1.0 & 0.24 & 2.681 & 0.008 & 0.47 \\
\hline Total NAS & 20.7 & 3.31 & 20.9 & 2.57 & -0.641 & 0.521 & - \\
\hline Total CSAS & 88.9 & 4.99 & 90.4 & 5.50 & -2.555 & 0.011 & 0.29 \\
\hline
\end{tabular}

MUW - Medical University of Warsaw; UB - University of Basel; M - mean; SD - standard deviation; PAS - positive attitude scale; NAS - negative attitude scale; CSAS - Communication Skills Attitudes Scale

* Student's t-test

** Cohen's $d$ (effect size: $0.20-0.49$ small; $0.50-079$ intermediate; $\geq 0.80$ large)

regarding their attitude towards learning communication skills was similar (M: 2.9/5 for MUW and UB) to the result obtained by Rees et al. [32].

Molinuevo and Torrubia [14], in their paper concerning the attitude of students of medicine and nursing towards communication skills, emphasised that communication skills are indispensable in relations between health care professionals and patients. The authors also pointed out that good communication leads to a greater accuracy in diagnosis, observing the recommended treatment, a better sense of the patient's well-being and satisfaction, and fewer complaints related to abuse. The authors report that attention is paid not only to learning and developing skills, but also to observing them and developing a positive attitude.

Students participating in the study by Molinuevo and Torrubia [14] evaluated their communication skills on a 4 -point scale ( 1 - poor, 2 - medium, 3 - good, and 4
- excellent), mainly as good (57.2\%) or medium (34.0\%). In the current study, the majority of students evaluated their communication skills as good (49.4\%). Over a fifth of respondents were not able to evaluate their own skills (28.0\%). A comparison of 3 groups of students - Spanish participating in the study carried out by Molinuevo and Torrubia [14], and Swiss and Polish students presented in the current study, revealed differences in the attitudes towards learning communication skills - Spanish students presented a positive attitude compared to the other groups (M: 4.18/5 versus 2.9/5).

To sum up, regardless of country, the results indicate a neutral attitude in students of medical schools towards the validity of learning communication skills.

Limitations of the study. The respondents represented 2 universities, therefore the study population cannot be 
regarded as representative for students from these countries. The results of this pilot study will help in the planning of further studies on a representative group of students of medical faculties.

\section{CONCLUSIONS}

The attitude of the studied population towards communication skills was neutral. Despite scientific evidence for the positive effects of good communication skills on the relationship between patients and health professionals, the participants in the current study were not aware of the importance of these skills. This finding underscores the need to invest in the teaching of communication skills in the medical curricula.

Currently, the problem of communication skills is noticed in almost every country in the world. The governments of the countries concerned and international organizations spend money trying to promote the development of soft skills. However, the authors of the study believe that it would be reasonable to include communication competences in the classroom during both the theory and general development classes, as well as clinical practices in hospital units.

\section{REFERENCES}

1. Tan T, Zhou H, Kelly M. Nurse-physician communication - An integrated review. Journal of Clinical Nursing. 2017; 26 23-24: 3974-3989.

2. Australian Commission on Safety and Quality in Health Care. Standard 6. Clinical Handover. Safety and Quality Improvement Guide. 2012; Available from: https://www.safetyandquality.gov.au/wp-content/ uploads/2012/10/Standard6_Oct_2012_WEB.pdf.

3. Interprofessional Education Collaborative. Core competencies for interprofessional collaborative practice: 2016 update. 2016 [cited 2018 13th June]; Available from: http://www.aacn.nche.edu/educationresources/IPEC-2016-Updated-Core-Competencies-Report.pdf.

4. Woloschuk W, Harasym P, Temple W. Attitude change during medical school: a cohort study. Med Educ. 2004; 38(5): 522-34.

5. Powerhouse H.C. Euro Health Consumer Index. 2017; Available from: https://healthpowerhouse.com/media/EHCI-2017/EHCI-2017-report. pdf.

6. Collins S, Hewer I. The impact of the Bologna process on nursing higher education in Europe: A review. International Journal of Nursing Studies. 2014; 51: 150-156.

7. Lahtinen P, Leino-Kilpi H, Salminen L. Nursing education in the European higher education area - Variations in implementation. Nurse Education Today. 2014; 34: 1040-1047.

8. MNiSW, Obwieszczenie Ministra Nauki i Szkolnictwa Wyższego z dnia 9 stycznia 2018 r. w sprawie ogłoszenia jednolitego tekstu rozporządzenia Ministra Nauki i Szkolnictwa Wyższego w sprawie standardów kształcenia dla kierunków studiów: lekarskiego, lekarsko-dentystycznego, farmacji, pielegniarstwa i położnictwa (Dz.U. 2018 poz. 345). 2018.

9. Davies R. The Bologna process: the quiet revolution in nursing higher education. Nurse Educ Today. 2008; 28(8): 935-42.

10. Panczyk M, et al. Communication skills attitude scale: a translation and validation study in asample of registered nurses in Poland. BMJ Open, 2019. 9.

11.MUW. The Bioethics Committee of the Medical University of Warsaw. 2018; Available from: http://komisja-bioetyczna.wum.edu.
pl/content/szczeg\%C3\%B3\%C5\%82owe-informacje-oraz-wzorydokument $\%$ C3\%B3w.

12. Rees C, Sheard C, Davies S. The development of a scale to measure medical students' attitudes towards communication skills learning: the Communication Skills Attitude Scale (CSAS). Med Educ. 2002; 36(2): 141-147.

13. Koponen J, Pyörälä E, Isotalus P. Comparing three experiential learning methods and their effect on medical students' attitudes to learning communication skills. Medical Teacher. 2012; 34(3): e198-e207.

14. Molinuevo B, Torrubia R. Validation of the Catalan version of the communication skills attitude scale (CSAS) in a cohort of south European medical and nursing students. Educ Health (Abingdon) 2011;24(1): 1-13.

15. Power B, Lennie S. Pre-registration dietetic students' attitudes to learning communication skills. Journal of Human Nutrition and Dietetics. 2012; 25(2): 189-197.

16. Khashab S. Attitudes of Alexandria Medical Students towards Communication Skills Learning. J Egypt Public Health Assoc. 2006; 81(5-6): 355-372.

17. Ihmeideh F, Al-Omari A, Al-Dababneh K, Attitudes toward Communication Skills among Students'-Teachers' in Jordanian Public Universities. Australian Journal of Teacher Education. 2010; 35(4): 1-11.

18. Cleland J, Foster K, Moffat M. Undergraduate students' attitudes to communication skills learning differ depending on year of study and gender. Medical Teacher. 2005; 27(3): 246-251.

19. Shankar R, et al. Student attitudes towards communication skills training in a medical college in Western Nepal. Educ Health (Abingdon). 2006; 19(1): 71-84.

20. Harlak H, Dereboy C. Gemalmaz A. Validation of a Turkish translation of the Communication Skills Attitude Scale with Turkish medical students. Educ Health (Abingdon). 2008; 21(1): 1-11.

21. Harlak H, et al. Communication skills training: effects on attitudes toward communication skills and empathic tendency. Education for Health. 2008; 21(2): 1-6.

22. Fazel I. Aghamolaei T. Attitudes toward learning communication skills among medical students of a university in Iran. Acta Medica Iranica. 2011; 49(9): 625-629.

23. Marambe K, Edussuriya D, Dayaratne K, Attitudes of Sri Lankan medical students toward learning communication skills. Education for Health. 2012; 25(3): 165-171.

24. Busch A, et al. Do medical students like communication? Validation of the German CSAS (Communication Skills Attitude Scale). GMS Zeitschrift für Medizinische Ausbildung. 2015; 32(1): 1-21.

25. Alotaibi F, Alsaeedi A. Attitudes of medical students toward communication skills learning in Western Saudi Arabia. Saudi Med J. 2016; 37(7): 791-795.

26. Anvik T, et al. Assessing medical students' attitudes towards learning communication skills-which components of attitudes do we measure? BMC Medical Education. 2007; 7(4): 1-7.

27. Laurence B, et al. Adaptation of the Communication Skills Attitude Scale (CSAS) to dental students. Journal of Dental Education. 2012; 76(12): 1629-1638.

28. Ahn S, Yi Y, Ahn D. Developing a Korean communication skills attitude scale: comparing attitudes between Korea and the West. Med Educ. 2009; 43(3): 246-253.

29. Bandura A, and Walters R. Sociallearning and personality development. New York: Holt, Rinehart, and Winston, 1963.

30. Wood W, Tanner K, The Role of the Lecturer as Tutor: Doing What Effective Tutors Do in a Large Lecture Class. CBE-Life Sciences Education. 2012; 11(1): 3-9.

31. Nor N, Yusof Z, Shahidan M. University of Malaya dental students' attitudes towards communication skills learning: implications for dental education. Journal of Dental Education. 2011; 75(12): 1611-1619.

32. Rees C, Sheard C. Evaluating first-year medical students' attitudes to learning communication skills before and after a communication skills course. Medical Teacher, 2003. 25(3): 302-307. 


\title{
Ocena postaw studentów kierunków medycznych Warszawskiego Uniwersytetu Medycznego oraz Uniwersytetu w Bazylei wobec kształcenia kompetencji komunikacyjnych
}

\author{
I Streszczenie \\ Wprowadzenie. Umiejętności komunikacyjne personelu medycznego w istotny sposób wpływają na efektywność procesu \\ terapeutycznego oraz bezpieczeństwo pacjenta. Pozytywne postawy wobec nauki tych kompetencji mogą w przyszłości \\ skutkować chęcią ich dalszego rozwoju. \\ Cel. Celem pracy była ocena postaw polskich i szwajcarskich studentów kierunków medycznych wobec konieczności \\ kształcenia w zakresie kompetencji komunikacyjnych. \\ Materiał i metody. W badaniu pilotażowym wzięło udział 261 studentów Warszawskiego Uniwersytetu Medycznego \\ (MUW) oraz Uniwersytetu w Bazylei (UB). Dobrowolne, anonimowe badanie ankietowe przeprowadzono za pomocą \\ standaryzowanego kwestionariusza CSAS, składającego się z 26 stwierdzeń, ocenianych w pięciostopniowej skali Likerta, \\ tworzących dwie podskale postaw - pozytywną (PAS) i negatywną (NAS). Różnicę pomiędzy postawami studentów z Polski \\ i Szwajcarii oceniano przy użyciu testu t-Studenta. \\ Wyniki. Zarówno polscy, jak i szwajcarscy studenci prezentowali neutralne postawy wobec nauki kompetencji \\ komunikacyjnych. Przy czym postawy studentów UB były nieco bardziej pozytywne niż studentów MUW (UB: 90,4/130 \\ vs MUW: 88,9/130, $\mathrm{t}=2,555, p=0,011)$. W odniesieniu do samooceny umiejętności komunikacyjnych uzyskane wyniki \\ kształtowały się na niskim poziomie (średnia w przedziale od 2,2 do 2,7/5). Nie wykazano także istotnych statystycznie \\ różnic w tym zakresie między studentami z obu krajów. \\ Wnioski. Neutralne postawy mogą w przyszłości negatywnie wpływać na efektywną i skuteczną współpracę zarówno \\ z pacjentem, jak i z członkami zespołu interdyscyplinarnego. Zasadne jest uzupełnienie programu nauczania na studiach \\ medycznych o treści z zakresu nauki komunikacji.
}

\section{Słowa kluczowe}

kompetencje miękkie, skala oceny postaw wobec nauki umiejętności komunikacyjnych, studenci, komunikacja z pacjentem, komunikacja w zespole terapeutycznym 